\title{
THE DEVELOPMENT OF DESTINATION ATTRACTIVENESS BY USING MARKETING TOOLS
}

\section{РОЗВИТОК ПРИВАБЛИВОСТІ ДЕСТИНАЦІЇ НА ОСНОВІ ВИКОРИСТАННЯ МАРКЕТИНГОВИХ ІНСТРУМЕНТІВ}

The rise of new business tourism destinations in many developing economies of the world is researched in the article. Destination's internal qualities are the key aspects in tourism development. There are the attractiveness, infrastructure, accessibility and services of the destination. In a competitive market environment every company (not only tourist one) can meet the demand of the market and achieve profitability by using marketing tools. It is very important for tourist companies to cooperate with the government and to work in tourism industry on the higher level. It can not only help to improve financial indicators of the country, but also influence greatly on the image of the country in the world. At the same time, tourist companies should be oriented on the following marketing functions: the analysis of market opportunities; the choice of perspective target market; the designation of tourist product; the retail of tourist product; the promotion of tourist product; the participation of realization of national, regional, local concepts of tourism marketing development. Also incentive tours are classified on such categories: by the number of participants; by the place of the event; by the objective; by the purpose; the elements of destination attractiveness are defined.

Keywords: business tourism, destination attractiveness, marketing, tourism attractiveness, tourist product.

The market for business tourism services and facilities is affected by the accelerating rate of innovation in information and communications technology. On the one hand, it offers significant opportunities for the development of more attractive business tourism products, but, on the other hand, may also create certain threats to the long-term prosperity of this sector. At the same time, developing economies create additional demand for business tourism events as their new businesses add to the need for corporate events, and members of the expanding professional classes increasingly have the means to travel to conferences and exhibitions in other countries.

This phenomenon is particularly seen in China and India, two of the world's fastest growing economies, and countries widely believed to be major sources of international business tourism consumption in the years to come. These two countries represent two economies that are set to generate the greatest expansion in outbound business travel for the short and medium term [7, p. 285]. Among European countries which receive corporate business travelers' flows, Germany, UK, France, Netherlands, Italy, Spain, Sweden, and Switzerland can be highlighted.

Tourism marketing has a number of features related to the specifics of the market and to the tourism product, which is offered on this market. With the increasing demand for tourist services the most important task of marketing activity in tourism is not the stimulation of demand itself, but the opportunity to manage and distribute it as for the seasons and geographic areas [17].

Destination's internal qualities are the key aspects in tourism development. The premises for the development are the attractiveness, infrastructure, accessibility and services of the destination. Attractiveness is the ability to captivate by some special features, qualities, properties. In scientific literature, devoted to tourism, it is noted that the concept of attraction is the main and decisive in the study of people's flows. Tourist attractiveness of the territory is formed primarily with the presence of natural or historical and cultural tourism resources, and even better when they are combined. Generally, the area is considered to be attractive for tourists, when it is popular among tourists and becomes proper territorial tourist combination in the form of a tourist item, center, hub, district, and region [14, p. 200-215].

In a competitive market environment every company (not only tourist one), regardless of size and directions of activity, by using marketing tools for the successful operation, can meet the demand of the market and achieve profitability. Marketing is a human activity aimed to meet the needs and requirements of the market. The scope of marketing has recently expanded by including, in addition to goods, services, organizations, places also the information. The notion of marketing services emerged and tourism belongs to this area $[15$, p. 57-60]. 
It is very important for tourist companies to cooperate with the government and work in tourism industry on higher level. It can not only help to improve financial indicators of the country, but also influence greatly on the image of the country in the world. Besides, it may raise the awareness of the country, attract more tourists, as well as the branding of the destination, concept of marketing tools are also to be implemented.

There are certain levels of marketing in tourism sphere [11, p. 315]:

-marketing of tourism companies (tour agents and tour operators); marketing of tourism services manufacturers (hotels, restaurants, transportation companies, etc.);

- marketing of public tourism organizations (associations, etc.); marketing of territories and regions (municipalities, city councils, departments, i.e. governmental level).

That is why the government together with other institutional units (tourist enterprises, local governments, associations and unions, etc.) is integrated in the system of marketing in tourism.

To the division of marketing functions should be paid special attention. Let us distinguish marketing functions by the level of marketing in tourism. The crucial marketing tasks of national and local tourism authorities are [11]: conducting of market research; the development of strategic national, regional and local marketing concepts with recommendations for their implementation for tourism companies; the support (investment and legal) of tourist infrastructure development; the creation of attractive image of the country (region, city); the implementation of activities with public relations and advertisement.

At the same time, tourist companies should be oriented on the following marketing functions: the analyses of the market opportunities; the choice of perspective target market; the designation of tourist product; the retail of tourist product; the promotion of tourist product; the participation of realization of national, regional, local concepts of tourism marketing development.

In the context of business tourism, it is closely connected with marketing activities. Because, basically, business trips are connected with the advertising of the company the person represent or the product, or the country. For instance, congress and exhibition tourism is the most dynamic segment of the business travel market. Under the congress and exhibition tourism one can understand the activities related to the organization of congresses, exhibitions, fairs, conferences and other events. According to statistics of the World Trade Organization (WTO), the share of congress and exhibition tourism in total business travel is 10-12\% [9].

The combination of congresses and exhibitions indicates that their concept is related. Differences occur at some specifics, relating mainly to the groups and requirements for infrastructure of the host side. In particular, a requirement for consolidation by the host direction reputation, which allows it to gain an international recognition, is one of the main conditions of congress and exhibition tourism. Usually, a country, which successfully develops congress and exhibition tourism, is one of the leaders in scientific and technical areas, which enables it to attract primarily professionals and gradually expand the range of visitors. The degree of economic development and the level of development of new technologies, transport infrastructure, communications and hotel base are an important condition for attracting participants of congress exhibition events.

Congress tourism is the form of exhibition tourism. To allocate congress tourism in small unit is necessary so that the organization of congress activities that have a lot to do with the organization of exhibitions imposes other requirements for infrastructure and organizers. Congress events are smaller in scale than the exhibitions, but are more qualified and demanding to the list of participants [10, p. 100-115].

Congress tourism has one distinctive feature - it has to be a major corporate customer: the government, individual ministries, large corporations, and holding companies. Events, which are arranged at government level or with the support of government circles, are able to increase its attractiveness in many times. So many congress organizers are trying to enlist the support of government circles to attract different kinds of international meetings on its territory [10, p. 100-115].

It is not accidently, that Kharkiv city is considered to be the city of congress and business events, as it has been already mentioned above. The annual International Tourism Forum is the best example of such event. It has been already held 8 times in Kharkiv. This complex event can be characterized, first of all, as the example of congress and exhibition tourism in the city; secondly, this event is organized and coordinated by local government - the International Cooperation Office of Kharkiv City Council; thirdly, it attracts to cooperate with local businesses (e.g. hotel and restaurant infrastructure to provide accommodation and catering, transportation companies - to provide transportation services; local newspapers and publishers - to enlighten this event in mass media, to promote it with the help of advertising, social networks, etc.). And, what is also important - it attracts foreign visitors - the invitation of special guests, speakers, etc. Generally, this 
event is organized by the government, but it is supported by other participants of organization process - local businesses or other governmental bodies.

If to focus on such event as the example of congress and exhibition tourism in Kharkiv, it can be said that according to the tourism development strategy of Kharkiv the identification of those areas that motivate visitors to visit the city is an important step towards the development of a tourist destination. In order to expand the market of tourism products, aimed at active business travelers, the city should develop business tourism. The concept of forum is aimed at sharing experiences in the field of tourism infrastructure development of cities and in image policy with foreign partner cities and international experts, theorists and practitioners of tourism industry and related services; the strengthening of interregional and international relations, partnerships, enhanced cooperation with partner cities, establishment of contacts between the representatives of tourism industry. In addition, holding to this international forum, is enlightened not only in local media, but also in foreign ones, so that the information and positive feedback of the visit of official delegations of partner cities can coerce to visit Kharkiv in order to obtain positive emotions and new experiences by other tourists. Taking into account the positive experience of implementation of similar projects, the problem and mechanisms for their implementation are evident, referred to the Strategy of tourism development in Kharkiv, in order to promote the city's tourism industry as a whole [2].

The exhibition movement is gaining strength and popularity worldwide. A number of exhibitions expand its geography and number of participants, becoming more diverse in its direction. Currently specialized exhibitions of hotel and restaurant business, sports, environmental, educational, medical and health and congress tourism are conducted. In the short term, this segment of tourist market has become one of the largest and most stable.

Along with trips to congresses and exhibitions business tourism includes incentive tours. The concept of "incentive" is interpreted as motivating that encourages. Under this type of tourism trips, there are supposed trips that commercial firms reward their employees for high performance in work or motivate them to more productive work in the future, and on-site seminars, meetings and conferences. Incentive tourism has several objectives: presentation and promotion of new products or services; improvement of productivity and quality; creation of a dealer and agent network; formation of a loyal and cohesive team.

Depending on the purpose, there are three types of incentive programs: encouraging (incentive) programs; motivational programs; team building [10, p. 100-115]. According to O. V. Babkin [10, p. 100-115] there are two types of incentive tours: private tours and on-site seminars, conferences. But this classification, for the author's opinion, is not relevant because the structure of the classification is not homogeneous. He also divided it by the purpose and objective. Hence, it is better to unify and combine it and classify incentive tours on such categories: by the number of participants; by the place of the event; by the objective; by the purpose.

All the changes are reflected in Fig. 1, designed by the author.

The share of incentive business travel sector accounts for only $8 \%$.Total annual turnover of European incentive tourism is US 4.5 billion [10, p. 100-115].

The usage of travel as a reward for progress in the work was put in 60's of the XX century in the USA. Only in 1970 - 1980's with the expansion of the flow of awarded tourists from America to the old continent, it has covered Europe and then was borrowed by Asia.

It was that time, when there were built specially five-star hotels in Europe and Asia. About $80 \%$ of incentive trips were accounted by Europe, $10 \%$ - in the US, $6 \%$ - in South East Asia, $4 \%$ - in other areas. The ratings of incentive destinations by European tourists are led by France, Spain, Switzerland, Austria, Cyprus, the USA and the Caribbean Islands [10, p. 100-115].

Group trips remain the dominant segment of the market of incentive tourism, despite the decline in their share of the early 1980 's. The number of tourists in incentive group can vary from a few to 100 people or more. The growing number of incentive tours helped to spur the expansion of subjects of congress and exhibition activities of specialized forums of encouraging tourism [10, p. 100-115].

All these forms of attractiveness refer to tourist destination. The attractiveness as a factor that attracts tourists to certain location could be presented as a mix of many elements. The attractiveness of the destination or attractive factors in the destination is the determining force that affects the concrete choice by the tourists. In times of expansion of the tourism and especially the hotel industry in the last two decades the participants of international tourist market as a place for offer-demand perceive the communication with modern terminology which, in fact, reflects the changes in market relations. Namely from marketing perspective the change in promotion of the national tourist product with a priority to promote the image of the destinations in 
one country on account of promotion of the national offer of another country is perceived. In that sense it is necessary to emphasize the complexity of the structure of factors that make the image of one tourist destination; and that is a guarantee for the satisfaction of the guest due to integrated realization of destination quality [5, p. 341-353].

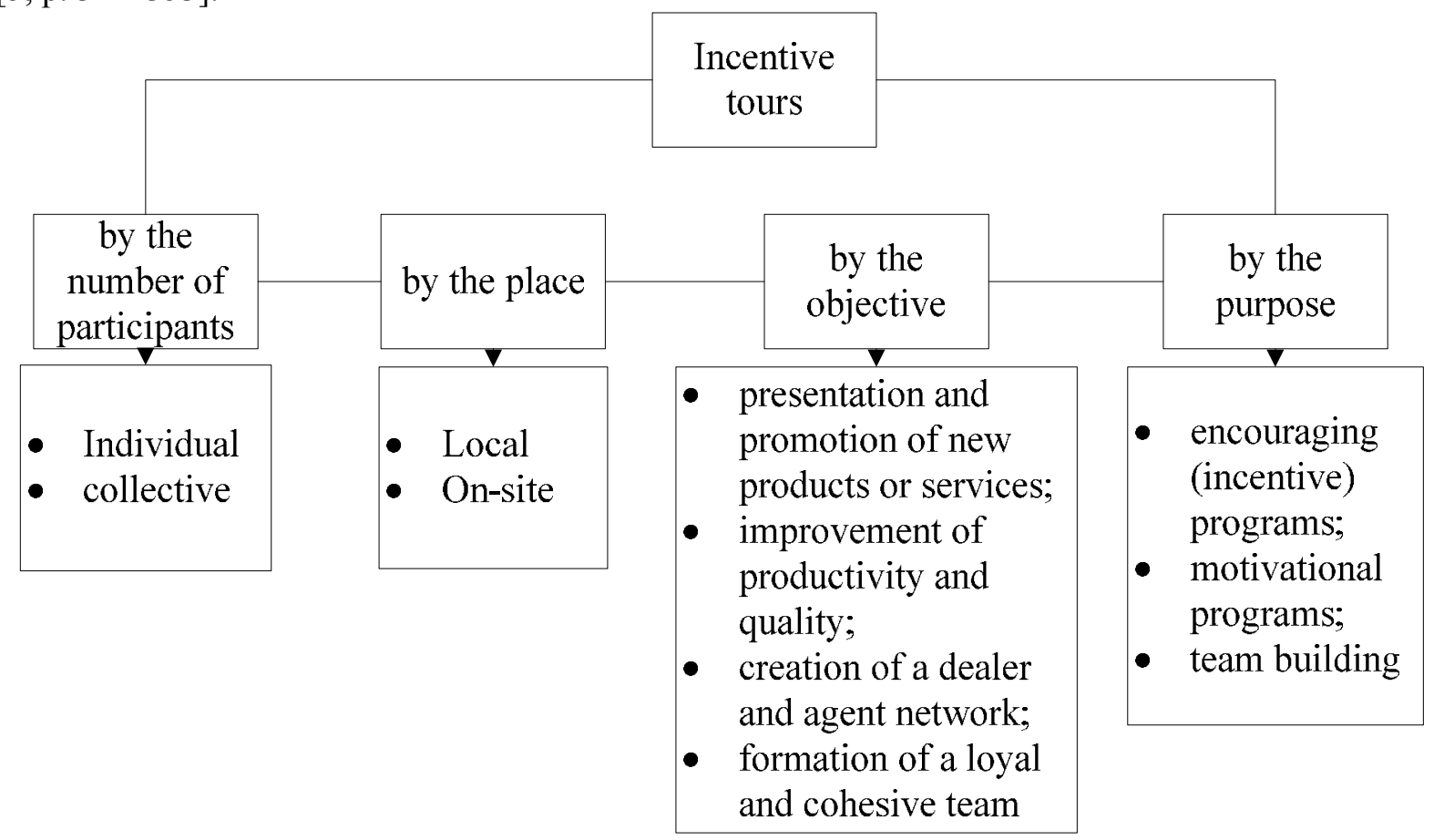

Fig. 1. The classification of incentive tours

Tourist flows of the country and the volume of provided tourist services are quantitative reflection of destination attractiveness. If to compare tourist flows in Ukraine, the number of tourists served by the subjects of tourism activity was 2425089 people in 2014, according to the Table 1, but in 2015 it decreased to 2019579 people.

According to the State Statistical Service of Ukraine [4], despite economic and political instability of the country, tourism industry is one of those industries, the annual indicators of which are increasing and have more or less positive dynamics of the development and some positive structural changes.

Table 1

Tourist flows during 2010 - 2015 in Ukraine

\begin{tabular}{|l|c|c|c|c|c|c|}
\hline \multirow{2}{*}{ Indicators } & \multicolumn{6}{|c|}{ Years } \\
\cline { 2 - 7 } & 2010 & 2011 & 2012 & 2013 & 2014 & 2015 \\
\hline \multicolumn{1}{c|}{1} & 2 & 3 & 4 & 5 & 6 & 7 \\
\hline $\begin{array}{l}\text { The number of } \\
\begin{array}{l}\text { Ukrainian citizens } \\
\text { who traveled } \\
\text { abroad - total }\end{array}\end{array}$ & 17180034 & 19773143 & 21432836 & 23761287 & 22437671 & 23141646 \\
\hline $\begin{array}{l}\text { The number of } \\
\text { tourists served by } \\
\text { the subjects of } \\
\text { tourist activity }\end{array}$ & 2280757 & 2199977 & 3000696 & 3454316 & 2425089 & 2019576 \\
\hline
\end{tabular}

It turns out that the importance of tourism for the country acts as a means of foreign exchange earnings, employment, and increased contribution to the balance of payments and GDP, economic diversification, increase of profits and improvement of the welfare of the nation. The dynamic development of tourism has a multiplying effect on other sectors of the economy in which there is an active investment, creation of new jobs and growing turnover. However, tourism is an activity that requires favorable economic conditions for developing and attracting significant amounts of financial resources. 
According to statistical data, given in the Table 2, it can be seen that the number of tourism enterprises during 2013 - 2014 has quite negative dynamics and is characterized by slight decrease in the number of tourist enterprises, while the volume of tourist services can't be compared with the previous year, but according to the data of $2006-2010$ it also decreased in a few times.

Table 2

The main indicators of tourist service market in Kharkiv region during $2006-2010$ and $2013-2014$

\begin{tabular}{|l|r|r|r|r|r|r|r|}
\hline \multirow{2}{*}{ Indicators } & \multicolumn{4}{|c|}{ Years [13] } & \multicolumn{2}{c|}{ Years [4] } \\
\cline { 2 - 8 } & 2006 & 2007 & 2008 & 2009 & 2010 & 2013 & 2014 \\
\hline $\begin{array}{l}\text { Number of tourist enterprises, } \\
\text { units }\end{array}$ & 164 & 302 & 426 & 546 & 719 & 358 & 309 \\
\hline $\begin{array}{l}\text { Volume of provided tourist } \\
\text { services, ths. UAH }\end{array}$ & 76103 & 105411 & 167408 & 169135 & 119806,5 & - & 28301 \\
\hline
\end{tabular}

Legal support of business activities in tourism is determined by the Laws of Ukraine [1-3]. The basis of the formation of entrepreneurial concepts may be imposed by following principles [16, p. 54-60]: market orientation of tourism services production; focus on profitability; focus on competitiveness; social orientation; self-regulation of economic behavior; focus on consumers of tourism services.

Global tourism market is becoming ever more competitive environment for tourism destination, due to large number of emerging destinations putting the mature ones under pressure to rejuvenate and to enhance their quality in order to remain competitive. Therefore, tourism destination should be innovative and continuously seek new sources of comparative advantages. Those comparative advantages, in the form of tourism resources and through adequate destination management and marketing strategies, could be transformed into tourism attractions and become competitive advantages which can provide long-term sustainable tourism growth and the development for tourism destination and therefore, improve its market positions [6, p. 497-517].

Destination attractiveness research is closely associated with the analysis of destination image since the notions of destination image and destination attractiveness are closely tied and conceptually interconnected, whereas the level of destination attractiveness is largely influenced by destination image, and vice versa. Destination attractiveness has a more cognitive connotation as it is a mental construct that exists only in the minds of potential visitors. It can be said that tourism attractions are physical manifestations of destination attractiveness and destination attractiveness is a mental image of the destination that is formed on the basis of physical attractions available in the destination [6, p. 497-517]. Summarizing the ideas above, the following scheme of destination attractiveness can be presented, it has been developed according to K. Pollard [8, p. 497-517] (Fig. 2).

The scheme is improved by adding such components as safety in destination environment, some other elements are united, like accessibility instead of travel convenience - access, or the time of travel is changed to the duration, because it unites the idea and makes more sense of understanding as in the author's opinion. Also, such element as "price" is specified as price level. If to consider infrastructure element, internal travels are excluded, because it is not always the measurement of destination attractiveness.

Taking into account Fig. 2, destination attractiveness can be measured by some particular elements, such as cultural and geographical proximity, infrastructure, destination environment, price level at the destination, its image. This list may be continued by any other element. Still, all mentioned above factors are one of the most important to the author's opinion. Cultural and geographical proximity are those factors that can be taken into account by tourists because usually the questions of crossing boarder or flight costs influence on the decision "to go there or not". Cultural issues - language and religion - are those factors that sometimes are not so vital, especially in the world of different multi-lingual devices, etc. Any tourist pays attention on the infrastructure of the country, its accommodation facilities and places to eat and to go. The environment of the country, the safety issues, political situation of the country - all these also influence on the decision-making process. Besides, the development of the tourism as an industry may be one of the most important factors, because tourism itself influences straightly on destination image, its attractiveness. This is inseparable component, which shows the level of tourist's awareness of these or that country/place. 


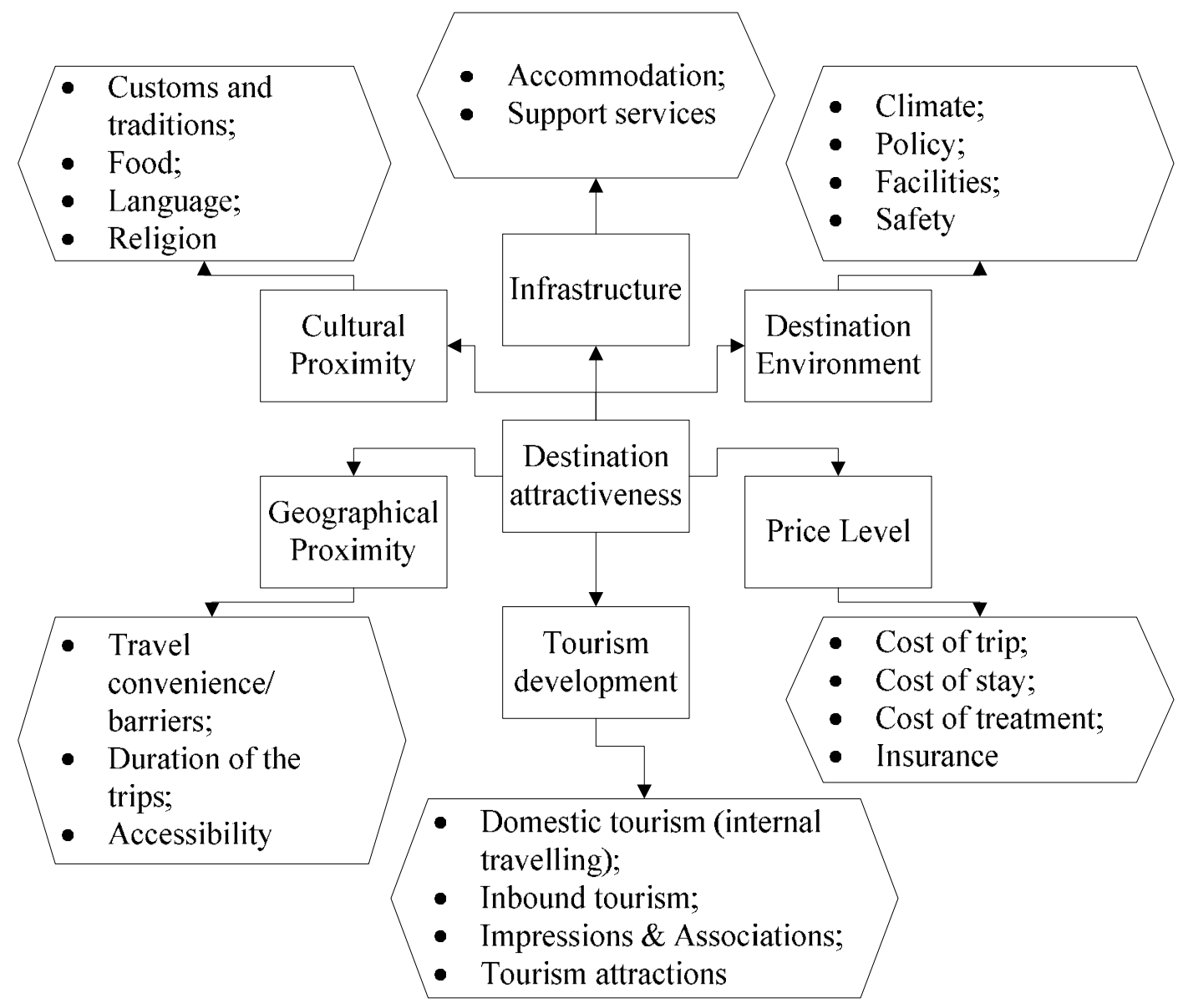

Fig. 2. The elements of destination attractiveness, based on $[8,13,14]$

Branding of the tourist destinations, on the one hand, based on the regional image, and on the other hand, influences on the formation of this image. Forming its own attractive tourist image plays an important role in the marketing of tourism destinations. The image destination is crucial to attract investors and consumers of tourism products. At the country level, the creation of a favorable image becomes a state task that largely determines the success of the development of the tourist complex. By the formation of the image refers to the process of establishing associative links of basic idea of the destination with any other presentation by repeatedly reproducing the relevant joint representations of objects in the frames of a single situation. When forming the destination image, it is determined by the kind of the target system - the possibility of recognition of the regions with accompanying updating relationships to this region [18, p. 20-34].

That is why, the task of destinations' branding as one of the tool of promotion is a purposeful formation of a positive tourist image of the country or region. Branding involves the creation of formalized and non-formalized brands, without which it is very difficult to promote tourism product in international tourism market today [18, p. 20-34].

The promotion of tourist destinations is increasing importance in product placement, it is a representation of a particular destination in movies and other works of art that allows reproducing in sufficient detail certain features and competitive advantages of a tourist region.

It is clear that event approach is also a very well-known and widely used in the world. In marketing communications to promote tourist destinations the measures of event nature, i.e. event marketing, for example, major international events, national, regional and local festivals, sporting events, unique natural phenomenon and others, are widely used.

As one of the tools to promote tourist destinations also the rating system can be applied. Extensive coverage of rankings and results in print, excitement and a certain intrigue at the announcement of the results are additional communications, positively affecting the image of destinations, which are included in the rating [11, p. 315]. For example, Kharkiv was announced as the best city for living in Ukraine in 2011 [5].At macrolevel the states are acting as the objects promoting individual countries perform on international tourist 
market. The state, facing international tourism market, comes in competitive relations with other countries, whole regions of the world. Tourist marketing strategy is reflected in the adoption of relevant legislation, government long-term programs and plans. The role and place of a particular state in the world tourist market depend on how properly, correctly and effectively a tourist marketing strategy is implemented and built [12]. The state tourism marketing strategy is focused on the creation, promotion, and implementation of national tourist product on the world market.

To sum up, basically, the goal of the implementation of marketing tools in the promotion of the destination is to attract tourists to the particular country/region/city. But it is very urgent not only to attract tourists from abroad, but to promote and develop domestic tourism, inside the country. As much local people are aware of the country's image, as more people abroad will know about it in the context of destination image. The tourism is the world's largest industry, responsible for more than one in ten jobs globally. In many developing and transition economies, the tourism has emerged as the dominant tool for economic growth. Good niches in business tourism exist for developing and transition economies. Business tourism is defined as leisure activities in conjunction with business travel. Developing and transition economies (like in Ukraine) are interested in expanding revenues from business tourism need to focus on both individual business traveler and the meetings and conventions.

\section{Список використаної літератури}

1. Закон України «Про внесення змін до Закону України «Про туризм» від 18.11.2003 № 1282-XV [Електронний ресурc]. - Режим доступу : www.rada.gov.ua

2. Про затвердження Стратегії розвитку туризму в місті Харкові [Електронний ресурс] / Реєстр актів Харківської міської ради від 23.09.2015 № 2045/15. - Режим доступу : http://kharkiv.rocks/reestr/643788

3. Закон України «Про туризм» від 15 вересня 1995 р. // Відомості Верховної Ради України. - 1995. - № 31. Ст. 241.

4. Статистичний бюлетень «Туристична діяльність в Україні» [Електронний ресурс] / Державна служба статистики України. - 2016. - Режим доступу : http://www.ukrstat.gov.ua

5. Blazeska D. The quality of the tourist destinatination a key factor for increasing their attractiveness / D. Blazeska, A. Milenkovski, S. Gramatnikovski // UTMS Journal of Economics. - 2015. - 6 (2). - P. 341-353.

6. Krešić D. Tourism original scientific paper / D. Krešić, D. Prebežac. - 2011 - Vol. 59, No. 4. -P. 497-517.

7. Holloway J. Christopher. The business of tourism / J. Chr. Holloway, C. Humphreys, R. Davidson. - Pearson Education Limited, 8th ed. - 2009. - $794 \mathrm{p}$.

8. Pollard K. How can we measure destination's attractiveness? [Electronic resource]. - 2012. - Access mode : https://www.imtj.com/blog/how-can-we-measure-destinations-attractiveness

9. The official web site of World Trade Organization. Statistics [Electronic resource]. - 2016. - Access mode : https://www.wto.org/english/res_e/statis_e/ statis_e.htm

10. Бабкін О. В. Спеціальні види туризму / О. В. Бабкін. - Ростов-на-Дону : Фенікс, 2008. - 252 с.

11. Дурович А. П. Маркетинг в туризме : учебное пособие / А. П. Дурович. - Минск : Новое знание, 2003. $496 \mathrm{c.}$

12. Карпова Г. А. Экономика и управление туристской деятельностью : учебное пособие в 2 ч. / Г. А. Карпова, Л. В. Хорева. - СПб. : Изд-во СПбГУЭФ, 2011. - Ч. 1. - 268 с.

13. Кулешова Н. В. Модель ідентифікації конкурентної позиції туристичних підприємств (на прикладі Харківської області) [Електронний ресурс]. - Режим доступу : http://repository.hneu.edu.ua/jspui/bitstream/.pdf

14. Любіцева О. О. Ринок туристичних послуг (геопросторові аспекти) / О. О. Любіцева. - К. : Альтерпрес, 2002. $-436 \mathrm{c}$.

15. Миронов Ю. Б. Використання маркетингу у сфері туризму / Ю. Б. Миронов. // Молодь і ринок. - 2002. № 1. - C. 57-60.

16. Нездоймінов С. Г. Вісник ДІТБ. Серія : Економіка, організація та управління підприємствами туристичної індустрії та туристичної галузі в цілому. - 2008. - № 12. - С. 54-60.

17. Смирнова О. А. Особенности развития делового туризма в Европейском регионе [Электронный ресурс] Режим доступа : http://tourlib.net/statti_tourism/smirnova2.htm

18. Тарасенок О. И. Маркетинг туристских дестинаций в контексте диалога культур / О. И. Тарасенок // Туризм та зближення культур : матеріали V Міжнар. наук.-практ. конф. - К. : Київ. ун-т туризму, економіки та права. $-2012 .-$ Ч. 1. - С. 20-34. 


\section{К. Наумік-Гладка}

\section{РОЗВИТОК ПРИВАБЛИВОСТІ ДЕСТИНАЦІЇ НА ОСНОВІ ВИКОРИСТАННЯ МАРКЕТИНГОВИХ ІНСТРУМЕНТІВ}

Внутрішні якості дестинації є ключовими аспектами в розвитку туризму. Мета статті полягає в тому, щоб визначити чинники розвитку дестинаиії і визначити маркетингові інструменти ї̈ розвитку. Вважається, що передумовами для розвитку дестинації є: привабливість, інфраструктуpa, доступність і послуги дестиначії. Масштаби маркетингу останнім часом поширилися, включивши, крім товарів, послуг, організацій та місиь, також інформацію. В статті обтрунтовано, щяо особливу увагу слід приділити поділу функцій маркетингу. Маркетингові функиії відрізняються в сфері туризму: проведення маркетингових досліджень; розробка стратегічних національних, регіональних і місиевих маркетингових концепиій з рекомендаціями щзоо їх реалізації для туристичних компаній; підтримка (інвестиційна і юридична) розвитку туристичної інфраструктури; створення привабливого образу країни (регіону, міста); здійснення заходів щодо зв'язків з громадськістю та реклами. Зроблено висновок про те, що бізнес-туризм включає інсентив-тури, крім того, глобальний ринок туризму стає все більш конкурентним середовищем. Також рекомендовано дослідити, що привабливість дестинації має тісний зв'язок з аналізом кінцевого іміджу, тому що поняття кінцевого іміджу і привабливість дестинації взаємопов'язані конщептуально, в той час як рівень иільової привабливості багато в чому залежить від иільового іміджу, $і$ навпаки.

Ключові слова: діловий туризм, привабливість призначення, маркетинг, туристична привабливості, турпродукт. 